\title{
Sociálně charitativní činnost církve v rámci moderních systémů sociální pomoci Tadeusz Kamiński
}

\begin{abstract}
Abstrakt:
Církevní a s církvemi spojené pomáhající organizace tvoří v mnoha zemích důležitou součást systémů sociálního zabezpečení. Takové subjekty, které jsou označovány jako Faith-Based Organisations, mají (nebo by měly mít) silně náboženský profil. Je to především teologicky zakotvená motivace, která je základem aktivity, ale i postoj k potřebným. Schopnost sjednotit materiální a duchovní pomoc je obzvláště důležitá. Hlavním problémem, kterému se článek věnuje, je tedy fungování teologicky založených organizací v oblasti veřejné sociální pomoci se zvláštním důrazem na katolickou Charitu. Nejprve jsou definovány základní pojmy. Poté jsou prezentovány politické podmínky a konkrétní oblasti sociálně charitativního závazku církve $v$ rámci systémů sociálního zabezpečení. $V$ poslední části jsou diskutovány skutečné a potenciální obtíže takové činnosti.
\end{abstract}

Klíčová slova: caritas, sociálně charitativní aktivity, sociální péče, Charita

Církevní a s církvemi spojené pomáhající organizace tvoří důležitou součást systémů sociální pomoci v řadě zemí. Tyto organizace, které jsou označovány jako Faith-Based Organisations, mají (nebo by měly mít) silně náboženský profil. V první řadě jde o teologicky zakotvenou motivaci, která je základem činnosti, ale také o př́stup $\mathrm{k}$ potřebným. Zvlášt důležitá je rovněž schopnost spojit materiální a spirituální pomoc. Hlavním problémem, kterému se tento článek věnuje, je tedy fungování pomáhajících organizací vycházejících z teologických základů, a to $\mathrm{v}$ rámci veřejné sociální pomoci se zvláštním zřetelem k situaci katolické Charity. Nejprve jsou definovány základní pojmy. Následně jsou představeny politické podmínky a konkrétní oblasti sociálně charitativní služby církve v rámci systémů sociální pomoci. V poslední části je pojednáno o reálných a potenciálních obtížích takovéto činnosti.

\section{Vyjasnění základních pojmů}

Pojem sociálně charitativní činnost lze definovat různým způsobem, pro další úvahy je však velmi vhodný následující koncept: „institucionalizovaná a organizovaná pomoc církve, pokud je zaměřena na odstranění sociální nouze a vytvoření poměrů, které odpovídají požadavkům spravedlnosti a lásky. Uskutečňuje se formami, které mají na zřeteli sociální danosti a změny, zůstává však vždy určována 
duchem lásky“. ${ }^{1} \mathrm{~V}$ takové definici lze vidět všechny důležité prvky, které odlišují pomáhající aktivity církevních organizací od jiných, tak rríkajíc sekulárních. Jde o institucionalizovanou a organizovanou pomoc církve, církev však musí být chápána jako společenství všech věřících. To znamená: sociálně charitativní služba je úkolem celé církve a zejména laiků. Poměry, které mají být takovou činností vytvářeny, mají odpovídat nejen požadavkům spravedlnosti, ale také lásky. Formy sociálně charitativní práce církve mají být určovány i duchem lásky. Míněna je zde přirozeně láska ve smyslu caritas.

Veřejná sociální pomoc se zabývá lidmi a jejich životními poměry. Pokud odstraníme z výše uvedené definice jen pár slov, dostaneme poměrně dobrou všeobecnou definici sociální pomoci: institucionalizovaná a organizovaná pomoc (...), je-li zaměřena na odstranění sociální nouze a vytvoření poměrü, které odpovídají požadavkům spravedlnosti (...) Uskutečňuje se formami, které mají na zřeteli sociální danosti a změny (...).

Podle Waltera A. Friedländera je sociální pomoc organizovaný systém sociálních služeb a zařízení, který podporuje jednotlivce a skupiny v tom, aby dosáhli uspokojivého životního a zdravotního standardu i sociálních vztahů, které jim umožní rozvinout jejich plnou kapacitu a umožní jim zdraví a blaho v souladu s potřebami jejich rodin a společnosti. ${ }^{2}$ Podle polského zákona o sociální pomoci patři sociální pomoc k zařízením sociální politiky státu, jejichž cílem je umožnit osobám a rodinám zvládnout obtížnou životní situaci, kterou nemohou zmoci vlastními prostředky, možnostmi a právy. Sociální pomoc je poskytována úřady státní a komunální správy ve spolupráci se soukromoprávními poskytovateli, katolickou církví, jinými konfesemi, jakož i právnickými a fyzickými osobami. ${ }^{3}$ Ve všech výše uvedených definicích jde o široké chápání sociální pomoci, které přesahuje pouhou oblast finanční podpory.

$\mathrm{Na}$ sociálně charitativní činnost církve lze nahlížet jako na specifickou formu sociální pomoci. Je to sociální pomoc stavějící na lásce $\mathrm{k}$ Bohu a k bližnímu. Jak lze číst v Dekretu o apoštolátu laiků II. vatikánského koncilu: „Laici tedy mají vysoce hodnotit a podle svých možností podporovat díla lásky a akce sociální pomoci, a to soukromé a veřejné, i mezinárodní. Jimi se poskytuje účinná pomoc jednotlivcům i celým národům, které se ocitnou v nouzi. V tom at spolupracují se všemi lidmi dobré vůle“. 4

Pastorální konstituce Gaudium et spes jasně rríká, že ve středu církevní péče o člověka stojí člověk ve své jednotě a úplnosti, s tělem i duší, srdcem i svědomím, myslí i vưlí. Církvi jde o spásu lidské osoby. Každý člověk má být zachráněn a lidská společnost obnovena. ${ }^{5}$ Pro charitativní službu a angažovanost křestanů v dnešní době to znamená, že by se neměla omezit na materiální pomoc. Potřební nejsou jen ti, kteří nemají denní chléb, nýbrž ti, kteří jsou vyloučeni z tak zvané moderní společnosti. A ti všichni potřebují i víru, naději a lásku, které stojí obvykle mimo zájem veřejné sociální pomoci. Sociálně charitativní činnost církevních pomáhajících organizací je tedy důležitým doplněním veřejné sociální pomoci, ovšem se svou vlastní úlohou.

\section{Politické podmínky a praktické oblasti sociálně charitativní činnosti církevních pomáhajících organizací v systémech sociální pomoci vybraných zemí}

Nejdůležitějším kontextem pro sociálně charitativní činnost v rámci systémů sociální pomoci je model vztahu státu a církve. Obecně máme v principu co do činění se dvěma modely - 1) jednot-

\footnotetext{
Richard VÖLKL, Nächstenliebe - Die Summe der christlichen Religion?, Freiburg i.Br.: Lambertus, 1987, s. 110-111

Srov. Walter A. FRIEDLÄNDER, Introduction to Social Welfare, New Jersey: Englewood Cliffs, 1961, s. 4.

Srov. Ustawa z dnia 12 marca 2004 o pomocy społecznej, čl. 2.

Apostolicam actuositatem, 8 .

Gaudium et spes, 3.
} 
ný systém / státní církev; 2) odluka církve od státu. V jednotném systému jde o to, že jedno náboženství je oficiálním státním náboženstvím a je státem různými způsoby podporováno. Model odluky funguje ve více variantách, které sahají od striktní odluky náboženství a státu ve veřejném prostoru až po rozmanité formy spolupráce. ${ }^{6} \mathrm{~V}$ následující části budou analyzovány politické podmínky sociálně charitativní činnosti církevních pomáhajících organizací ve vybraných státech, v nichž existuje model odluky. Jedná se o Francii, Německo a Polsko.

\subsection{Francie}

Francie je označována jako laicistický stát. Ze států Evropské unie dal pouze francouzský zákonodárce do textu ústavy expressis verbis princip sekularismu. Církve nejsou v ústavě vůbec zmíněny. Francouzský model odluky byl již na začátku 20. století zakotven ve dvou zákonech: v zákonu z 1. července 1901 o náboženských kongregacích a v zákonu z 9. prosince 1905 o odluce církví a státu. Bylo by tedy možné domnívat se, že sociálně charitativní činnost církve/církví je ve Francii silně omezená či dokonce nemožná. Laicita však způsobila, „že se v pozdější době sociální angažovanost či diakonie netýkala pouze chudých, nemocných či dětí, ale každé formy křestanského jednání v sociální oblasti - včetně odborových hnutí, politiky nebo vydavatelské činnosti“. ${ }^{8}$ Církve smějí napřr. zakládat obecně prospěšné organizace i v oblasti pomáhající činnosti, které mohou být státem finančně podporovány. Z hlediska státní či komunální správy přitom není náboženská orientace organizace relevantní, důležité jsou pro-sociální cíle její činnosti. ${ }^{9}$ Jednou z nich je Francouzská katolická charita (Secours Catholique), která byla v roce 1962 uznána jako obecně prospěšná organizace. ${ }^{10}$ Secours Catholique (tedy Katolická pomoc) je stále ještě největší obecně prospěšnou organizací ve Francii, alespoň co do počtu dobrovolníků a darovaných př́íspěvků. ${ }^{11}$

Celkově se Secours Catholique v roce 2015 skládala ze 76 delegací, které jsou rozděleny do 3600 místních skupin ve Francii a $\mathrm{v}$ zámoří. $\mathrm{K}$ tomu je třeba připočíst ještě tři pomocná místa (tzv. tykadla): městečko Saint-Pierre v Lurdech, dům Abraham v Jeruzalémě a svépomocnou skupinu pro žadatele o azyl a uprchlíky (CEDRE) v Paříži. Pracovalo v ní 67500 dobrovolníků a 971 zaměstnanců. V roce 2015 pomohla 1460000 lidí v 2400 pomocných zařízeních v celé Francii. ${ }^{12}$ Secours Catholique provozuje agentury, které se podílejí na poradenství a pomoci lidem v nouzi; svépomocné skupiny; sociální služby v oblasti krátkodobého ubytování pro lidi bez domova, bydlení pro bývalé bezdomovce a integraci osob se zdravotním postižením a se změněnou pracovní

6 Srov. Piotr BURGOŃSKI, Modele relacji między religią i państwem, in: Piotr BURGOŃSKI - Michał GIERYCZ (Hg.), Religia i polityka. Zarys problematyki, Warszawa: Elipsa, 2014, s. 218-230.

7 Srov. Krzysztof ORZESZYNA, Podstawy relacji między państwem a Kościołami w konstytucjach państw członkowskich i traktatach Unii Europejskiej, Lublin: Wydawnictwo KUL, 2007, s. 100.

8 Marc FEIX, Die Caritas im französischen Kontext, in: Klaus BAUMANN (Hg.), Theologie der Caritas. Grundlagen und Perspektiven für eine Theologie, die dem Menschen dient. Festschrift für Heinrich Pompë̈ aus Anlass seines 80. Geburtstages, Würzburg: Echter, 2017, s. 191.

9 Srov. Brigitte BASDEVANT-GAUDEMET, Państwo i Kościół we Francji, in: Gerhard ROBBERS (Hg.), Państwo i Kościół w krajach Unii Europejskiej, Wrocław: Kolonia Limited, 2007, s. 131.

10 Srov. Jean-Paul SCHNEIDER, Pädagogik der Nächstenliebe: Die französische Caritas und ihre Identität, in: Jan-Christof HORN und Heinrich POMPEY (Hg.), „Die Liebe Christi drängt uns” (2 Kor 5,14) - Caritaswissenschaftliche Forschung für caritativ-diakonisches Engagement, Band 3: „Geht hinaus in die Welt” (Mk 16,15) - Caritaswissenschaft in der Welt und für die Welt: Caritaswissenschaft International \& Caritaswissenschaft Interdisziplinär, Nordestedt: Books on Demand GmbH, 2005, s. 116.

11 Srov. Ingo BODE, A New Agenda for European Charity: Catholic Welfare and Organizational Change in France and Germany, Voluntas. International Journal of Voluntary and Nonprofit Organizations 2/2003, s. 209-210.

12 Srov. (C) Secoures Catholique - Caritas France, Rapport d’Activité 2015, https://www.secours-catholique.org/sites/scinternet/files/ publications/ra_20151.pdf, citováno dne 25. 11.2017. 
schopností na trhu práce. ${ }^{13}$ Kromě toho podporuje Secours Catholique množství sociálních podniků, které pracují v oblasti recyklace oblečení. Sociální podniky jsou financovány prostřednictvím systémů politiky trhu práce. ${ }^{14}$

Vedle samotné Secours Catholique existuje ve Francii Association des Cités du Secours Catholique (ACSC), která byla zapsána na pařížské prefektuře 1. června 1989. Jedná se o podjednotku Secours Catholique. Asociace se zabývá drogově závislými mladistvými, ženami v nouzi, muži bez domova atd. Provozuje rovněž zařízení pro pomoc lidem se zdravotním postižením s nabídkou dílen a speciálními nabídkami např. pro ubytování příbuzných pacientů, kteří byli hospitalizováni v nemocnici, či pro reintegraci zdravotně postižených manuálních pracovníků. ${ }^{15}$ Aktivity ACSC jsou finančně podporovány veřejnou správou, úřady dokonce zvýšily své investice do těchto služeb, kladou však vysoké požadavky na kvalitu služeb. Spolupráce s veřejnou správou však není vždy bezproblémová, nebot’ organizace např. nemá jistotu, zda v příštím roce získá dostatek prostředků na svou činnost. ${ }^{16}$

Spojení mezi sociálně charitativní činností a sociálním státem ve Francii se nyní ukazuje být podstatně silnějším než $\mathrm{v}$ minulosti. Tento krok však není bez negativ, jako v př́ípadě recyklačních společností. Veřejné dotace jsou omezené na určitou částku nebo na určitou dobu. V důsledku toho závisí přežití těchto projektů ve velké míře na vývoji trhu s recyklací oblečení. Protože sociální podniky musí konkurovat soukromým, je jejich ekonomická základna neustále ohrožena. $\mathrm{V}$ důsledku toho není práce $\mathrm{v}$ těchto podnicích „krokem směrem $\mathrm{k}$ jistotě“ ${ }^{17}$ Tyto obtíže se ovšem netýkají pouze církevních pomáhajících organizací. Souhrnně lze říci: ačkoli ve Francii existuje striktní model odluky církve od státu, mají církevní pomáhající organizace možnost realizovat svou diakonickou misi a působit v rámci systému sociální pomoci v partnerství s veřejnou správou.

\subsection{Německo}

Na rozdíl od svého francouzského protějšku představuje např. Německá katolická charita obrovský komplex agentur pracujících ve všech druzích sociálních služeb včetně péče o zdraví. ${ }^{18}$ To samé platí o evangelické Diakonii, která svou pomáhající činnost rovněž široce rozvinula. Bylo to možné, protože v Německu bylo vytvořeno silné, ústavně zakotvené, veřejné postavení církví. Toto postavení je založeno na dvou pilírích: „respektování maximální nezávislosti církví ze strany státu v úpravě jejich vlastních záležitostí a, na základě vzájemné nezávislosti, partnerská spolupráce ve prospěch celku ve všech otázkách a oblastech, v nichž církvím př́ísluší podle jejich sebepojetí zvláštní povinnost a kompetence. “ ${ }^{19}$ Právní řád v oblasti vztahu státu a církve je založený na třech principech: neutralitě, toleranci a paritě. Neexistuje státní církev, církev a stát jsou odděleny, ale mají se společně starat o potřeby lidí. ${ }^{20}$

Aby bylo možné lépe pochopit situaci církevních poskytovatelů pomoci v německém systému sociální pomoci, je nutno se nejdříve seznámit s ústavně zakotveným principem subsidiarity. Prin-

13 Srov. BODE, A New Agenda..., s. 210.

14 Srov. tamtéž, s. 220-221.

15 Srov. SCHNEIDER, Pädagogik..., s. 121.

16 Srov. IBODE, A New Agenda..., s. 220.

17 Tamtéž, s. 221.

18 Srov. tamtéž, s. 211.

19 David SEEBER, Caritas in Staat und Gesellschaft, in: Hellmut PUSCHMANN (Hg.), Not sehen und handeln. Caritas: Aufgaben, Herausforderungen, Perspektiven, Freiburg i.Br.: Lambertus, 1996, s. 188-189.

20 Srov. Gerhard ROBBERS, Państwo i Kościół w Niemczech, in: Gerhard ROBBERS (Hg.), Państwo i Kościół w krajach Unii Europejskiej, Wrocław: Kolonia Limited, 2007, s. 279. 
cip byl v encyklice papeže Pia XI Quadragesimo anno definován takto: „To, co mohou jednotlivci provést $\mathrm{z}$ vlastní iniciativy a vlastním přičiněním, to se jim nemá brát $\mathrm{z}$ rukou a přenášet na společnost. Stejně tak je proti spravedlnosti, když se převádí na větší a vyšší společenství to, co mohou vykonat a dobře provést společenství menší a nižši “ ${ }^{21} \mathrm{~V}$ Německu však byl princip subsidiarity dlouhou dobu chápán specificky: „co mohou volné společenské síly vykonat, nemělo by jim být odejmuto státními a komunálními institucemi“ ${ }^{22}$ Hovořilo se dokonce o principiální přednosti volné sociální péče (tzv. freie Wohlfahrtspflege, pozn. překl.), nebot podle $\$ 10$ Spolkového zákona o sociální péči, který od roku 1962 do roku 2004 upravoval způsob a rozsah sociální pomoci potřebným obyvatelům Spolkové republiky Německo, měli poskytovatelé sociální pomoci upustit od provádění některých opatření tam, kde mohla být zvažovaná pomoc poskytnuta v rámci volné sociální péče. ${ }^{23}$ Obdobu nalezneme v aktuálním Sociálním zákoníku, v němž byl vztah $\mathrm{k}$ volné sociální péči stanoven takto:

(1) Postavení církví a náboženských společností veřejného práva i svazů volné sociální péče jako zřizovatelů vlastních sociálních úkolů a jejich činnost při provádění těchto úkolů nejsou tímto zákoníkem dotčeny.

(2) Garanti sociální pomoci mají při provádění tohoto zákoníku povinnost spolupracovat s církvemi a náboženskými společnostmi veřejného práva stejně jako se svazy volné sociální péče. Dbají přitom na jejich samostatnost při stanovování cílů pro jejich úkoly a při jejich provádění.

(3) Spolupráce má být zaměřena na to, aby se sociální pomoc a činnost volné sociální péče účinně doplňovaly ve prospěch osob oprávněných pro poskytování podpory. Garanti sociální pomoci mají povinnost přiměřeně podporovat svazy volné sociální péče při jejich činnosti v oblasti sociální pomoci.

(4) Je-li podpora v jednotlivém případě poskytována volnou sociální péčí, pak mají garanti sociální pomoci upustit od provádění vlastních opatření. To neplatí pro poskytování finanční podpory.

(5) Garanti sociální pomoci obecně mohou do provádění svých úkolů podle tohoto zákoníku zapojovat svazy volné sociální péče nebo jim provádění těchto úkolů předat, jsou-li tyto svazy se zapojením nebo převedením srozuměny. Garanti sociální pomoci zůstávají zodpovědnými vưči osobám oprávněným pro poskytování podpory. ${ }^{24}$

Pro volnou sociální péči má interakce s veřejnou správou velký význam. V 90. letech 20. století však několik sociálních reforem změnilo pravidla hry. Všeobecná strategie veřejných úruadů nyní spočívá v nastavení ekonomického tlaku vůči poskytovatelům služeb, a to jak sjednáváním nových podmínek financování $\mathrm{z}$ veřejných zdrojů, tak systémem hospodářské soutěže. Stát začal projednávat nabídku služeb s poskytovateli ze sektoru obecně prospěšných organizací, aby otevřel volnou soutěž. ${ }^{25}$ Charita a jiní velcí volní poskytovatelé (např. Diakonie, Paritätischer Wohlfahrtsverband) postupně ztrácejí své privilegované postavení v systému. Charita však zůstává největším zaměstnavatelem v Německu, který provozuje přes 24000 zařízení.

\footnotetext{
PIUS XI, Quadragesimo Anno, 79.

SEEBER, Caritas..., s. 188.

Srov. tamtéž.

Sozialgesetzbuch (SGB XII), Verhältnis zur freien Wohlfahrtspflege, $₫ 5$.

Srov. BODE, A New Agenda..., s. 216.
} 
Tab. 1 Sociální zařizení Charity Německo

\begin{tabular}{|lr|}
\hline Oblast činnosti & \\
\hline Zdravotnická pomoc & 2.523 \\
Pomoc dětem a mladistvým & 11.510 \\
Pomoc rodinám & 892 \\
Pomoc seniorům & 2.913 \\
$\begin{array}{l}\text { Pomoc zdravotně postiženým / psychia- } \\
\text { tricky nemocným }\end{array}$ & 2.269 \\
Další sociální pomoc & 4.284 \\
CELKEM & 24.391 \\
\hline & \\
\hline Typy zařízení & 4.255 \\
Pobytová zařízení & 11.073 \\
Denní stacionáře & 8.644 \\
Služby sociální pomoci & 419 \\
Centra vzdělávání a dalšího vzdělávání & 24.391 \\
\hline CELKEM &
\end{tabular}

Zdroj: Statistika zařizení Charity Německo (stav k roku 2014),

https://www.caritas.de/cms/contents/caritas.de/medien/dokumente/dcv-zentrale/statistik/caritas-statistik-di/einrichtungsstatistik-caritas-2014_v2.pdf?d=a\&f=pdf, citováno dne 22. 10. 2017

Cca 620000 lidí pracuje profesně v zařízeních a službách, které jsou po celém Německu napojené na Charitu. Jsou podporováni zhruba půl milionem dobrovolníků (tzv. Ehrenamt) a dobrovolníků podle zákona o dobrovolnické službě z 31. ř́ijna 2007 (tzv. Freiwilligendienst) ve všech oblastech činnosti sociálně charitativní služby. ${ }^{26}$

Evangelická Diakonie je rovněž velkým zaměstnavatelem, který dlouhou dobu působí v oblasti sociálních služeb. Následující diagram k tomuto podává několik konkrétních číselných údajů.

26 Srov. (c) Caritas als Arbeitgeber, https://www.caritas.de/fuerprofis/arbeitenbeidercaritas/ arbeitgebercaritas/caritasalsarbeitgeber.aspx, citováno dne 22. 10. 2017. 


\subsection{7}

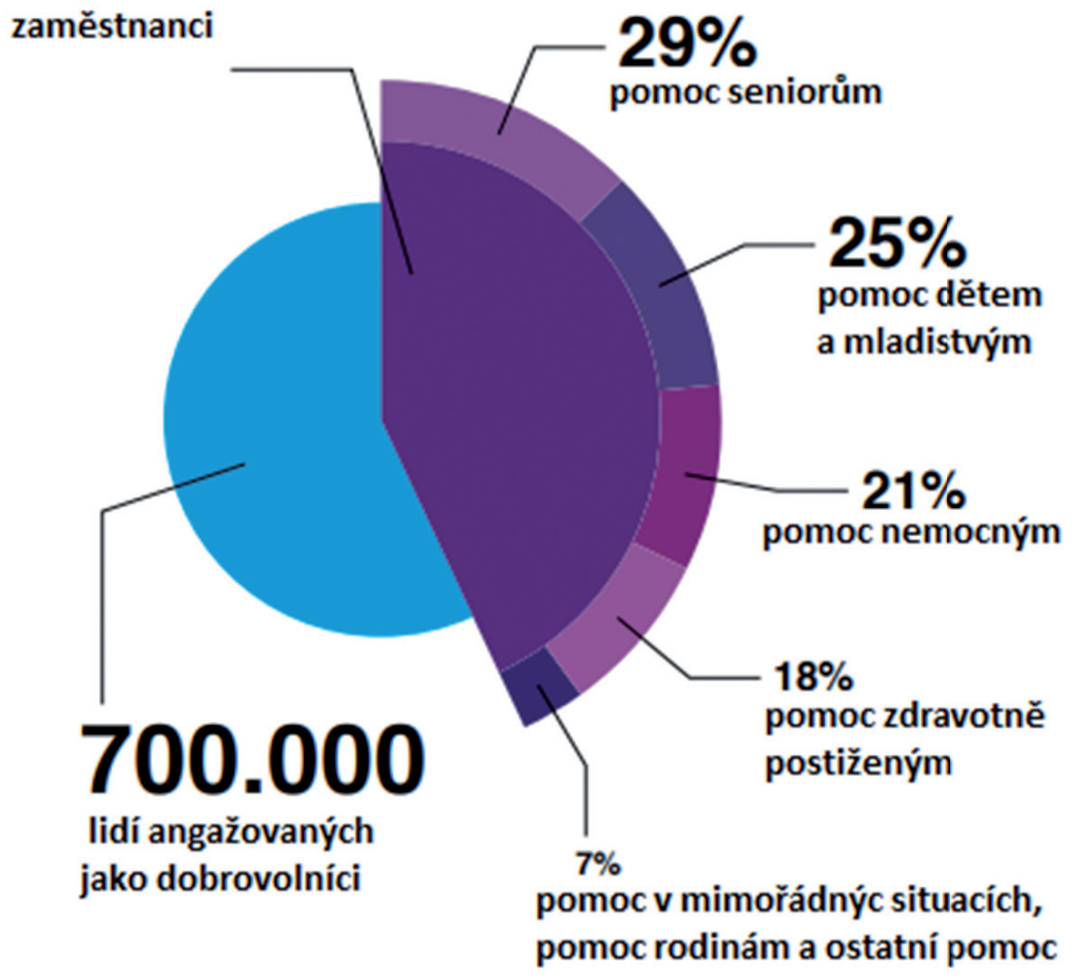

Zdroj: Diakonie v číslech, https://www.diakonie.de/infografiken/die-diakonie-in-zahlen/, citováno dne 22. 10. 2017

Přes všechny změny, které byly provedeny v systému sociální pomoci v posledních dvaceti letech, mají církevní pomáhající organizace v Německu široké možnosti působení a spolupráce se státem v řadě oblastí.

\subsection{Polsko}

Právo na charitativní činnost církve/církví v Polsku bylo potvrzeno v ústavě a konkordátu. Polská ústava ze 2. dubna 1997 stanoví, že církve a stát mají spolupracovat k blahu lidí a společnosti. Konkordát, podepsaný v roce 1993 a ratifikovaný až v roce 1998, rozhoduje, že charitativní činnost církevních právnických osob má být postavena na roveň sociální činnosti veřejných zařízení. Vztah státu a církví i ostatních náboženských společností v Polsku tedy lze stanovit jako model vzájemné nezávislosti a spolupráce. Podrobné úpravy spolupráce v oblasti sociální pomoci se nacházejí v několika zákonech, o kterých bude souhrnně pojednáno.

Podle Zákona o obecně prospěšné činnosti a dobrovolnictví z roku 2003 byla činnost církevních organizací postavena na roveň ostatním nestátním neziskovým organizacím. Proto smějí např. diecézní Svazy charity získat status obecně prospěšné organizace. Status obecně prospěšné organizace poskytuje různé daňové výhody, např̀. právo získat $1 \% \mathrm{z}$ daně z přijmu (Personal Income Tax). Zákon upravuje spolupráci mezi státním a nestátním sektorem, tedy i církevními organizacemi. Spolupráce zahrnuje především: 
a) smluvní realizaci veřejných úkolů náboženskými zařízeními;

b) vzájemnou výměnu informací o plánovaných oblastech činnosti;

c) podávání stanovisek k navrhované legislativě.

Podle Zákona o sociální pomoci z roku 2004 má být sociální pomoc organizována na místní a centrální úrovni v partnerství mj. s církvemi. Veřejná správa dává církvím úkoly z oblasti sociální pomoci a poskytuje příspěvky na jejich realizaci. To se děje na základě výběrových řízení. Každá církevní organizace tedy musí být účastníkem řízení spolu s dalšími poskytovateli. Na základě úpravy smí církve a církevní organizace provozovat domy s pečovatelskou službou, azylová zařízení, zařízení pro děti a mládež, specializovaná poradenská střediska a centra krizové intervence a být při této činnosti spolufinancovány.

V souladu s ustanoveními Zákona o podpoře rodin a systému péče o děti z 9. června 2011 mohou církevní organizace pomáhat rodinám formou poradenství, terapie, mediace a právní pomoci. Mohou rovněž organizovat zařízení pro děti a mládež. Zvláštní součástí jejich podpưrných aktivit pro děti je příprava pěstounských rodin a adopční řízení.

Důležitou oblastí činnosti Charity v Polsku je pomoc sociálně vyloučeným. Zmiňme zde Zákon o sociálním zaměstnávání ze 13. června 2003 a Zákon o sociálních družstvech z 27. dubna 2006. V prvním př́ípadě jsou církevní instituce oprávněné iniciovat a vést centra a kluby pro sociální integraci. Služby takových center jsou zaměřeny především na osoby bez domova, dlouhodobě nezaměstnané, závislé na alkoholu a drogách a také na zdravotně postižené. Krátce řečeno na typické př́ijemce církevní pomoci. Sociální družstvo je sdružení, které se zasazuje o sociální a profesní znovuzačlenění svých členů. Jádrem jejich činnosti je společný podnik založený na osobní práci vlastních členů. Lze tedy říci, že sociální družstvo nabízí dobrou formu svépomoci. Oprávnění zakládat sociální družstva mají v Polsku i církevní osoby a Charita tak činí.

Zákon o pracovní a sociální rehabilitaci a zaměstnávání zdravotně postižených lidí z 27. srpna 1997 umožňuje Charitě organizovat a realizovat pracovní terapii a rehabilitační pobyty. Kromě toho má právo vytvářet tzv. centra pro pracovní aktivity určená zdravotně postiženým.

Podle Zákona o podpoře zaměstnávání a institucích trhu práce z 20. dubna 2004 jsou církevní organizace oprávněné vést zařízení trhu práce. Jedná se zde o zprostředkování práce a profesní vzdělávání a další vzdělávání. Charita v této oblasti založila tzv. pracoviště pro aktivizaci nezaměstnaných.

Měli bychom rovněž zmínit Zákon o zdravotnických zařizeních ze 30. srpna 1991. Zákon umožňuje církvím provozovat např. nemocnice, zdravotnická centra, kliniky zaměřené na péči a léčbu, medicínská rehabilitační centra a hospice. Lze k nim přičíst i odvykací střediska pro osoby závislé na alkoholu a drogách.

Největší církevní pomáhající organizací v Polsku je katolická Charita. Její kořeny sahají až do roku 1920. V té době byla angažovanost církevních poskytovatelů sociální pomoci státem vítaná. V roce 1950 byla rozhodnutím komunistických úřadů Charita coby církevní organizace zrušena. Krátce před pádem komunismu, v květnu 1989, byl schválen Zákon o vztahu státu a katolické církve. V zákoně byly polská Charita a diecézní charity explicitně uvedeny jako právnické osoby katolické církve. V důsledku takového zákona došlo ke znovuoživení Charity a jako první započala svou činnost charita Diecéze opolské. Bylo to 9. listopadu 1989. Dne 10. ř́ina 1990 byla etablována Charita Polsko jako pastorační instituce Polské biskupské konference. ${ }^{27}$ Struktura Charity v Polsku se nyní sestává z:

27 Srov. Tadeusz KAMIŃSKI, Caritas i polityka. Podmioty wyznaniowe w systemie pomocy społecznej, Warszawa: Wydawnictwo UKSW, 2012, s. 239-244. 
- Charita Polsko;

- 41 charit římsko-katolických diecézí;

- 2 charity řecko-katolických diecézí;

- Charita Ordinariátu polského polního vojska;

- Charita Hospitálského řádu sv. Jana z Boha;

- Charita Pallottinů;

- 4406 skupin farních charit;

- 560 školních okrsků charity.

Specializovaná zařízení jsou provozována většinou diecézními charitami, mnohé jsou však organizovány farními charitami. Konkrétní čísla podle druhu zařízení jsou uvedena v tabulce 2.

Tab. 2. Sociální zařízení Charity Polsko

\begin{tabular}{|lr|}
\hline Druh zařízení & Počet \\
Domovy pro těhotné ženy a matky s dětmi & 15 \\
\hline Domovy pro oběti násilí & 67 \\
\hline Denní stacionáře pro děti & 605 \\
Dětské domovy & 12 \\
Centra pro adopční řízení & 4 \\
\hline Domy s pečovatelskou službou pro seniory & 55 \\
Kluby a denní stacionáře pro seniory & 19 \\
\hline Charitní střediska sociální péče & 175 \\
\hline Domácí a lǒžkové hospice & 43 \\
Poradenská centra a terapeutická zařízení pro osoby závislé na alkoholu a drogách & 4 \\
\hline Dílny pracovní terapie & 62 \\
\hline Chráněné a podporované bydlení & 67 \\
\hline Aktivizační centra pro nezaměstnané & 10 \\
\hline Centra pro sociální integraci & 3 \\
\hline Kluby pro sociální integraci & 9 \\
\hline Zařízení pro osoby bez domova a jiná centra pomoci pro osoby bez domova & 95 \\
Kuchyně pro chudé & 109 \\
\hline Centra pomoci pro migranty a uprchlíky & 5 \\
\hline
\end{tabular}

Zdroj: W służbie ludziom. Raport roczny 2010 Caritas w Polsce, passim.

Zprávy některých diecézních charit ukazují, že jsou spolehlivým partnerem místní samosprávy a v některých př́padech (jako např. pomoc osobám bez domova) i ústřední správy. Ke státním úřadům spolupracujícím s Charitou patří: Ministerstvo pro rodinu, práci a sociální politiku, Ministerstvo vnitra a administrativy, Státní fond pro rehabilitaci osob se zdravotním postižením, Kancelář Senátu či Agentura pro agrární trhy. Na místní úrovni je to místní samospráva, městská správa, okresní správa a zemské úřady. Nejen organizace diecézní charity, ale i farní charity jsou 
ceněnými poskytovateli sociálního podpůrného systému na lokální úrovni, o čemž svědčí i to, že jejich aktivity jsou zahrnuty do místních strategií řešení sociálních problémů. ${ }^{28}$

\section{Obtíže/rizilka sociálně charitativní činnosti v rámci veřejné sociální pomoci}

Pro církevní pomáhající organizace, které spolupracují s veřejnou správou v oblasti sociální pomoci, existuje několik výhod. Je to např. možnost získat pravidelnou finanční podporu za realizovanou činnost, a vybudovat si tak jako poskytovatel služeb stabilní postavení. Díky tomu je pak možné investovat do vlastní infrastruktury a zaměstnávat profesionální zaměstnance. Je však třeba zmínit zvláště některá rizika, která při tom mohou vzniknout. Některá z nich se týkají všech nestátních neziskových organizací (NGO’s), některá jsou specifická pro Faith-Based Organisations.

Pokud jde o rizika týkající se všech NGO’s, existují dvě nejdůležitější. ${ }^{29}$ Za prvé je to částečná nebo dokonce úplná ztráta nezávislosti na státních strukturách. NGO’s by měly být a zůstat ve všech oblastech nezávislé na státu, protože je to jejich poznávací znamení. Smlouvy a s nimi spojené finance $z$ veřejných/státních institucí mohou zapř́ičinit, že formálně nestátní organizace bude fungovat podobně jako státní agentura. Jsou přijímána pravidla veřejné správy, která nejsou vždy vhodná pro angažovanost ze strany volné sociální péče. Je zde míněna např. velká byrokracie. Hovoří se tedy o zestátnění nestátních neziskových organizací. Stát nebo místní samospráva by chtěly takovéto organizace kontrolovat, jsou-li jim přidělovány finance. Je to pochopitelné, ale může to vést $\mathrm{k}$ dalekosáhlému zásahu do autonomie organizace. Druhým nebezpečím pro všechny nestátní neziskové organizace je nebezpečí komercializace činnosti. Organizace přebírají obchodní pravidla, aby byly konkurenceschopnější na otevřeném trhu sociálních služeb. Fungují-li však NGO’s jako firma, může dojít k tomu, že ti, kteří potřebují pomoc, budou považováni za klienty, kteří slouží pouze zisku.

Existují i rizika, která jsou specifická pro církevní pomáhající organizace. Organizace např. mohou ztratit svou vlastní identitu, budou-li považovány pouze za řádného zaměstnavatele. V tomto kontextu je třeba zmínit bouřlivou diskusi o tzv. Leitbildu Charity, která byla v Německém charitním svazu vedena před téměř 30 lety. Tehdy řada pracovníků německé Charity přiznala, že jejich práce nemá vůbec nic společného $s$ vírou, tzn. v rámci církevní instituce pracují i ti, kteří víru v Boha ve své pomáhající činnosti považují za irelevantní. Hovořilo se dokonce o „rostoucí sekularizaci církevních organizací Diakonie a Charity“.30 A nyní, v době nepřetržité profesionalizace a ekonomizace je to velmi aktuální nebezpečí.

Církevní poskytovatelé sociální pomoci by se proto měli starat o svou hodnověrnost nejen coby organizace poskytující profesionální pomoc, ale i jako organizace, která je zakotvená ve víře. Musí odvádět vysoce kvalitní práci a zůstat v souladu s vlastní duchovní misií. Je nutné být věrohodný jak pro úřady, tak pro věřící. Někdy to může být obtížné, nebot velmi často závisí na ideologické orientaci místní samosprávy, zda církevní organizace dostane šanci ucházet se o realizaci úkolů v oblasti sociální pomoci. I když se to podaří, mohou být uloženy těžké podmínky, např. v zařízení pro osoby bez domova, které je podporováno $z$ veřejných prostředků, nesmí být sloužena mše svatá. Něco takového může sponzor požadovat a organizace musí plnit smluvní podmínky.

V sociálně charitativní činnosti církevních organizací hrají významnou roli dobrovolníci. Většinou přebírají úkoly, které nevyžadují žádné zvláštní odborné schopnosti. Existují však i dobro-

28 Srov. tamtéž, s. 285-287.

29 Srov. Piotr FRĄCZAK, Organizacje pozarządowe a państwo - w poszukiwaniu równowagi, Trzeci Sektor 20/2010, s. 35.

30 Josef ERNST, Caritas: Biblisch, in: P. Eicher (Hrsg.), Neues Handbuch theologischer Grundbegriffe, Mnchen: Kösel, 1991 , svazek 1, s. 255. 
volníci, kteří jsou vysoce kvalifikovaní a mohou i v důchodovém věku pomáhat. Problém spočívá $\mathrm{v}$ tom, že se v řadě zemí chce v sociální oblasti angažovat stále méně lidí. Snižuje se rovněž ochota přispívat na charitativní práci církve. ${ }^{31}$ Pro organizace, které jsou založené především na dobrovolnické práci a soukromých př́íspěvcích, je velmi obtížné nadále pokračovat ve svých aktivitách.

\section{Závěr}

Sociálně charitativní činnost zůstává důležitým úkolem církve a jednotlivých křestanů v dnešním světě, ačkoli v mnoha zemích existují rozvinuté systémy veřejné sociální pomoci. Rámec pro tyto aktivity je utvářen vztahem státu a církve a dokonce tam, kde funguje striktní model odluky (např. ve Francii), mají církve možnost spolupracovat se státem ve prospěch těch, kteří potřebují pomoc. Pro církevní organizace je velmi důležité zachovat si při takové činnosti vlastní identitu a neproměnit se v typické nestátní neziskové organizace či tržní subjekty.

Překlad: Mgr. et Mgr. Jana Maryšková

\section{Kontakt}

\section{Dr. hab. Tadeusz Kamiński}

Institut für Politikwissenschaften

Kardinal-Stefan-Wyszynski-Universität in Warszawa

t.kaminski@uksw.edu.pl 